\title{
PERANGKAT LUNAK 3D MODELLING PROPERTI SEBAGAI MEDIA PEMASARAN MENGGUNAKAN AUGMENTED REALITY BERBASIS ANDROID PADA PERUMAHAN GRAHA CIPTA HERTASNING
}

\author{
Nurkhalik Wahdanial Asbara \\ STIE Nobel Indonesia Makassar \\ Email : khalikwahdanial@stienobel-indonesia.ac.id
}

\begin{abstract}
ABSTRAK
Penelitian ini bertujuan untuk menghasilkan sebuah aplikasi yang dapat menampilkan model rumah berbentuk 3 dimensi dalam lingkungan Augmented Reality sehingga dapat membantu para pembeli untuk mengetahui secara fisik rumah yang akan mereka beli juga untuk membatu pihak marketing perusahaan properti untuk mengelola pemasaran rumah dengan menampilkan informasi spesifikasi rumah. Hasil dari penelitian adalah Aplikasi yang dapat menampilkan gambar rumah 3D dan denah rumah 3D pada saat menyorot marker sesuai arah dari marker objek brosur yang disorot. Metode yang digunakan dalam pembuatan aplikasi AR adalah Superimposition Based Augmented Reality. Metode Pengujian Sistem menggunakan metode pengujian langsung berdasarkan teknik Black Box dengan menguji fungsionalitas dari aplikasi, tombol dan kesesuaian hasil aplikasi.
\end{abstract}

Kata Kunci : Augmented Reality, Rumah, Pemasaran.

\begin{abstract}
This study aims to produce an application that can display a 3D house model in an Augmented Reality environment so that it can help buyers to physically see the house they are going to buy as well as to help property company marketing to manage the house by displaying information on house specifications. The result of the research is an application that can display $3 D$ house images and $3 D$ house plans when highlighting the marker in the direction of the highlighted brochure marker object. The method used in making AR applications is Superimposition Based Augmented Reality.The System Testing Method uses a direct test method based on the Black Box technique by testing the functionality of the application, buttons and the suitability of the application results.
\end{abstract}

Keyword : Augmented Reality, House, Marketing

\section{PENDAHULUAN}

Rumah merupakan kebutuhan mutlak bagi manusia untuk itu perumahan atau bisnis properti dapat menjadi salah satu peluang aset bisnis yang menjanjikan dan menguntungkan bagi para pencari peluang bisnis, dan salah satu yang memanfaatkan peluang tersebut adalah PT Cipta Kreasi Multiguna yang membuka lahan perumahan yang diberi nama Perumahan
Graha Cipta Hertasning. Walaupun perkembangannya belum pesat karena pemasarannya masih menggunakan media 2D yang berupa brosur. Pemanfaatan tekhnologi sekarang menjadi sesuatu tuntutan yang begitu massif seperti yang disampaikan oleh (Latief, 2019) menyatakan bahwa saat ini masyarakat sudah tidak bisa dipisahkan dengan tekhnologi. Penggunaan tekknologi yang 
massif juga terlihat di bidang sistem Informasi Manajemen sebagai salah satu media untuk membangun komunikasi secara efektif termasuk kepentingan komunikasi di bidang marketing (Idris \& Hidayat, 2020). Teknologi AR (Augmented Reality) atau dikenal sebagai 'realitas tertambah' merupakan salah satu teknologi baru di bidang multimedia. AR didefinisikan sebagai teknologi yang dapat menggabungkan dunia nyata dengan dunia maya, bersifat interaktif menurut waktu nyata (real time), serta berbentuk animasi 3D. Teknologi AR dapat dimanfaatkan untuk membantu pemasaran rumah dalam bisnis properti sehigga dapat memberi contoh rumah sebernarnya yang digantikan dengan tampilan 3D (3 dimensi) secara virtual dengan menggunakan perangkat mobile sehingga para pengusaha properti dapat menghemat biaya untuk membuat miniatur rumah dengan menggantikan hal tersebut dengan perangkat lunak ini.

Penelitian ini membahas tentang perancangan aplikasi mobile berbasis augmented reality menggunakan metode Superimposition Based Augmented Reality, dimana metode ini merupakan suatu teknik pada markeles augmented reality yang dapat mengganti sebagian atau seluruh tampilan asli dari suatu objek dengan pandangan yang baru dan ditambah objek yang sama. Pendeteksian objek sangatlah penting karena aplikasi tidak dapat menggantikan tampilan asli dengan augmented jika tidak dapat menentukan apa objek itu.

Penelitian ini bertujuan untuk menghasilkan sebuah aplikasi yang dapat menampilkan model rumah berbentuk 3 dimensi dalam lingkungan Augmented Reality sehingga dapat membantu para pembeli untuk mengetahui secara fisik rumah yang akan mereka beli juga untuk membantu pihak marketing perusahaan properti untuk mengelola pemasaran rumah dengan menampilkan informasi spesifikasi rumah.

\section{LANDASAN TEORI}

2.1. Visualisasi Menurut Anditya (2008:69), Visualisasi adalah upaya nyata seseorang untuk mentransformasikan ide atau gagasannya kepada orang lain, baik sekelompok audience atau publik dalam bentuk media gambar yang bersifat mudah dipahami. Maka sebuah visualisasi tentu mempunyai tujuan untuk menyampaikan maksud suatu ide atau gagasan yang melatar belakanginya. Dalam dunia arsitektur, visualisasi sering disebut dengan teknik presentasi.

\subsection{Tiga Dimensi}

Menurut Handi Chandra (2012:4), 3 dimensi atau biasa disingkat 3D atau disebut ruang, adalah bentuk dari benda yang memiliki panjang, lebar, dan tinggi. Istilah ini biasanya digunakan dalam bidang seni, animasi, komputer dan matematika.

\subsection{Augmented Reality (AR)}

Menurut Perey (2011) Visi kami di masa depan adalah bahwa setiap materi yang dicetak, dimulai dari poster, paket yang dikirim, halaman dari koran, majalah atau buku, dapat memberikan nilai bila dikombinasikan dengan kamera, algoritma dapat mendeteksi isi halaman dan platform yang mengambil data digital yang berhubungan. Kombinasi dari sistem AR (Augmented Reality) dengan media cetak akan memberikan nilai lebih dibandingkan 
dengan sesuatu yang hanya dicetak saja atau konten digital saja.

Menurut (Asbara, 2020) Spesifikasi perangkat (android) mulai dari ukuran fixel kamera, ukuran RAM berpengaruh besar dalam menjalankan suatu aplikasi.

\subsection{Perumahan}

Berdasarkan UU Nomor 4 Tahun 1992 tentang Perumahan dan Pemukiman, Rumah adalah bangunan yang berfungsi sebagai tempat tinggal atau hunian dan sarana pembinaan keluarga. Sedangkan perumahan adalah kelompok rumah yang berfungsi sebagai lingkungan tempat tinggal atau lingkungan hunian yang dilengkapi dengan prasarana dan sarana lingkungan.

\subsection{Jenis-Jenis Rumah}

Menurut Suparno (2006), dalam perumahan, jenis rumah diklasifikasikan berdasarkan tipe rumah Jenis rumah tersebut terdiri atas:

a) Rumah Sederhana

Rumah sederhana merupakan rumah bertipe kecil, yang mempunyai keterbatasan dalam perencanaan ruangnya. Mempunyai luas rumah rata-rata $22 \mathrm{~m} 2 \mathrm{~s} / \mathrm{d}$ $36 \mathrm{~m} 2$, dengan luas tanah $60 \mathrm{~m} 2 \mathrm{~s} / \mathrm{d} 75 \mathrm{~m} 2$.

b) Rumah Menengah

Merupakan rumah bertipe sedang. Pada tipe ini, cukup banyak kebutuhan runag yang direncanakan dan perencanaan ruangnya lebih leluasa. Pada umunya rumah sederhana mempunyai luas rumah $45 \mathrm{~m} 2 \mathrm{~s} / \mathrm{d} 120 \mathrm{~m} 2$, dengan luas tanah $80 \mathrm{~m} 2$ s/d 200m2.

c) Rumah Mewah

Merupakan rumah bertipe besar, perencanaan ruang pada rumah bertipe ini lebih kompleks karena kebutuhan ruang yang dapat direncanakan banyak dan disesuaikan dengan kebutuhan pemiliknya. Pada umunya rumah mewah mempunyai luas rumah lenih dari $120 \mathrm{~m} 2$ dengan luas tanah lebih dari $200 \mathrm{~m} 2$.

\subsection{Android}

Menurut Nazaruddin Safaat $H$ (2011:6) "Android adalah sistem operasi untuk telepon seluler yang berbasis Linux. Android menyediakan platform terbuka bagi para pengembang buat menciptakan aplikasi mereka sendiri untuk digunakan oleh bermacam peranti bergerak. Awalnya, Google Inc. Membeli Android Inc, pendatang baru yang membuat peranti lunak untuk ponsel. Kemudian untuk mengembangkan Android, dibentuklah Open Handset Alliance, konsorsium dari 34 perusahaan peranti keras, peranti lunak, dan telekomunikasi, termasuk Google, HTC, Intel, Motorola, Qualcomm, T-Mobile, dan Nvidia."

\subsection{Black Box}

Menurut Roger S. Presman (2010:78) "Pengujian black box testing berfokus pada persyaratan fungsional perangkat lunak. Dengan demikian, pengujian black-box memungkinkan perekayasa perangkat lunak mendapatkan serangkaian kondisi input yang sepenuhnya menggunakan semua persyaratan fungsional untuk suatu program. Pengujian black-box bukan merupakan alternatif dari teknik white-box, tetapi merupakan pendekatan komplementer yang kemungkinan besar mampu mengungkap kelas kesalahan daripada metode white-box."

Pengujian black-box berusaha menemukan kesalahan dalam kategori sebagai berikut :

a) Fungsi-fungsi yang tidak benar atau salah.

b) Kesalahan interface 
c) Kesalahan dalam struktur data atau database eksternal

d) Kesalahan kinerja

e) Instalisasi dan kesalahan terminasi

\section{METODE PENELITIAN}

Pada kegiatan penelitian ini, Penulis menggunakan beberapa metode yang dijadikan sebagai cara pengumpulan data yang dibutuhkan, yaitu :

a) Metode Observasi

Observasi adalah pengamatan langsung terhadap suatu kegiatan yang sedang dilakukan. Di sini penulis melakukan pengamatan secara langsung kegiatan pemasaran perumahan Graha Cipta Hertasning.

b) Metode Dokumentasi

Metode yang digunakan dengan mencari data mengenai hal-hal atau variabel yang berupa tipe atau model rumah.

Tahapan-tahapan atau langkahlangkah pokok yang penulis lakukan dalam kegiatan penelitian terdiri dari :

a) Pengumpulan Data, yang dilakukan dengan menggunakan metode-metode yang telah disebutkan di atas

b) Analisis sistem, yang dilakukan dengan menggunakan instrumen-instrumen yang ada.

c) Desain sistem, yang mencakup perancangan program berdasarkan hasil analisis yang telah dilakukan sebelumnya.

d) Pembuatan Program, yaitu melakukan pengkodingan program dalam bahasa pemrograman.

e) Pengujian sistem, digunakan untuk mengukur efisiensi dan efektifitas alur logika pemrograman yang telah dirancang dengan menggunakan metode pengujian Black Box.

f) Implementasi, yaitu penerapan sistem yang telah dibuat untuk diaplikasikan oleh masyarakat.

\section{HASIL DAN PEMBAHASAN}

Sistem yang berjalan pada pemasaran perumahan Graha Cipta Hertasning saat ini dalam memasarkan produknya masih menggunakan media brosur. Dimana media brosur yang diberikan kepada pengunjung kurang efektif karena pengunjung kurang memperhatikan brosur yang sudah diberikan.

\subsection{Use case Diagram}

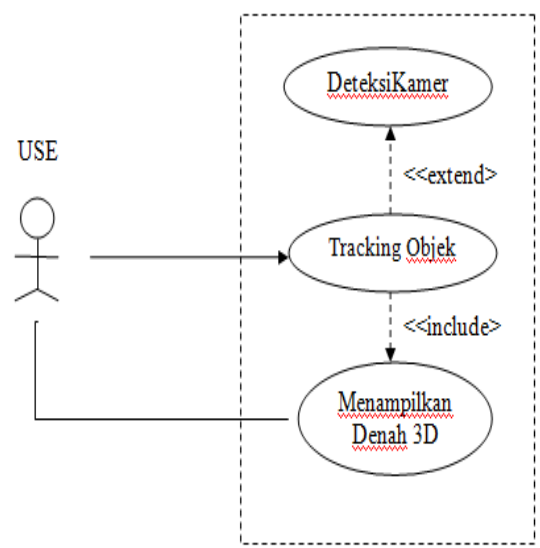

Gambar 1. Use Case Diagram

4.2. Pengujian mejalankan aplikasi

a) Pengujian Capture Objek(Brosur) Tabel 1. Tampilan Capture Objek

\begin{tabular}{|c|c|c|}
\hline $\begin{array}{c}\text { Mengaktifkan } \\
\text { Aplikasi }\end{array}$ & $\checkmark$ & $\begin{array}{c}\text { Berhasil } \\
\text { menampilkan } \\
\text { objek dari } \\
\text { camera ponsel }\end{array}$ \\
\hline & Screenshoot \\
\hline
\end{tabular}


b) Pengujian Marker Rumah (Tampak Luar)

Tabel 2. Tampilan marker rumah (tampak luar)

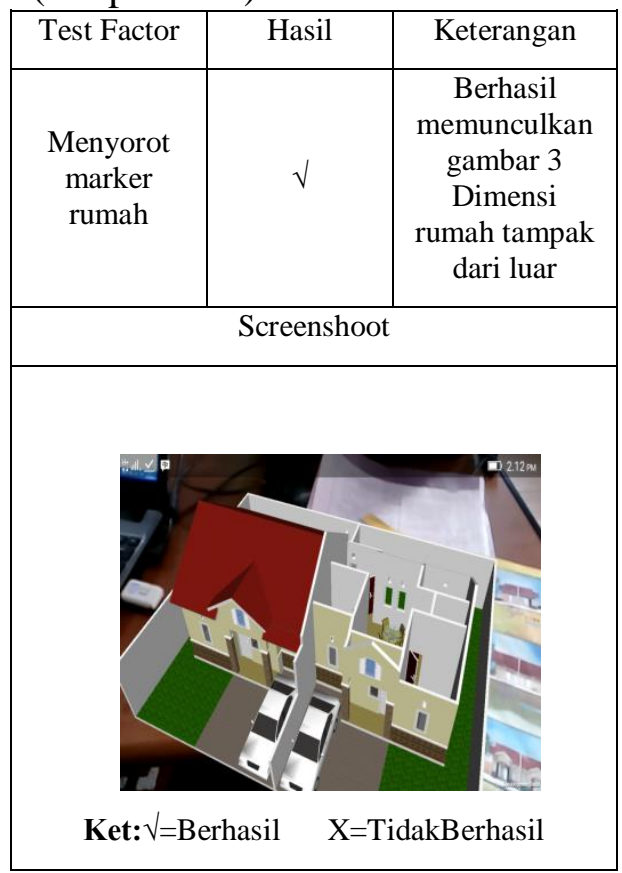

c) Pengujian marker rumah (tampak dalam)

Tabel 3. Tampilan marker rumah (tampak dalam)

\begin{tabular}{|c|c|c|}
\hline $\begin{array}{c}\text { Test } \\
\text { Factor }\end{array}$ & Hasil & Keterangan \\
\hline $\begin{array}{c}\text { Menyorot } \\
\text { marker } \\
\text { rumah }\end{array}$ & $\sqrt{ }$ & $\begin{array}{c}\text { Berhasil } \\
\text { memunculkan } \\
\text { gambar 3 } \\
\text { Dimensi } \\
\text { rumah } \\
\text { tampak dari } \\
\text { dalam }\end{array}$ \\
\hline & Screenshoot \\
\hline
\end{tabular}

d) Tampilan Form Booking Rumah

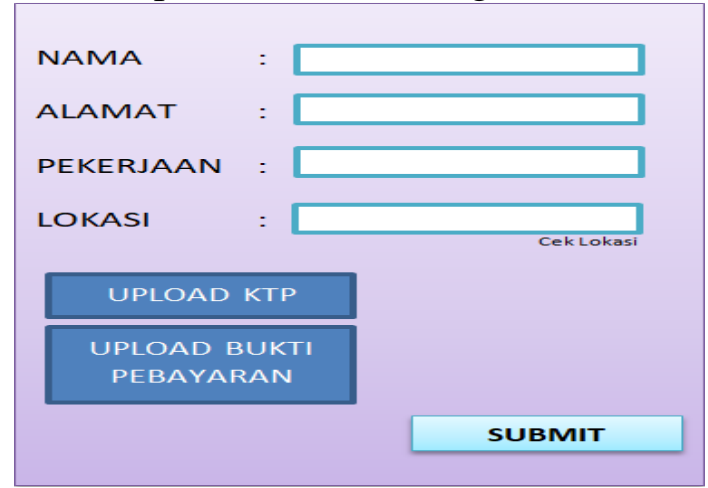

Gambar 2. Tampilan Form Booking Rumah

e) Tampilan Cek Lokasi

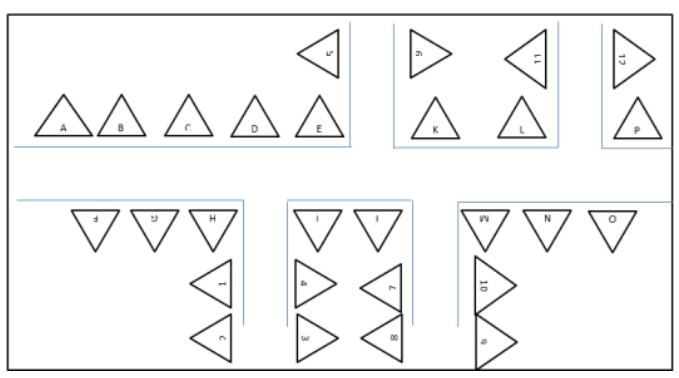

Gambar 3. Tampilan Cek Lokasi

\subsection{Hasil Pengujian}

Berdasarkan teknik pengujian Black Box yang telah dilakukan maka secara umum hasil pengujian aplikasi dapat disimpulkan sebagai berikut :

Tabel 4. Pengujian Black Box

\begin{tabular}{|c|c|c|c|c|}
\hline $\begin{array}{l}\mathrm{N} \\
\mathrm{O}\end{array}$ & $\begin{array}{c}\text { Skenario } \\
\text { Pengujian }\end{array}$ & $\begin{array}{l}\text { Hasil yang } \\
\text { diharapkan }\end{array}$ & $\begin{array}{c}\text { Hasil } \\
\text { Penguji } \\
\text { an }\end{array}$ & $\begin{array}{c}\text { Kesi } \\
\text { mpul } \\
\text { an }\end{array}$ \\
\hline 1 & $\begin{array}{l}\text { Mengaktif } \\
\text { kan } \\
\text { Aplikasi }\end{array}$ & $\begin{array}{l}\text { Sistem akan } \\
\text { mengaktifka } \\
\mathrm{n} \text { kamera } \\
\text { ponsel }\end{array}$ & $\begin{array}{l}\text { Sesuai } \\
\text { Harapan }\end{array}$ & $\begin{array}{l}\text { Vali } \\
\text { d }\end{array}$ \\
\hline 2 & $\begin{array}{l}\text { Menyorot } \\
\text { marker } \\
\text { brosur } \\
\text { rumah }\end{array}$ & $\begin{array}{l}\text { Aplikasi } \\
\text { akan } \\
\text { menampilka } \\
\text { n gambar } 3 \\
\text { Dimensi } \\
\text { Rumah } \\
\text { tampak dari } \\
\text { luar dan } \\
\text { dalam }\end{array}$ & $\begin{array}{l}\text { Sesuai } \\
\text { Harapan }\end{array}$ & $\begin{array}{l}\text { Vali } \\
\text { d }\end{array}$ \\
\hline
\end{tabular}


Perbedaan mendasar system ini dengan system yang sudah ada yaitu dengan tersedianya menu booking rumah sehingga pelanggan tidak perlu datang dilokasi untuk booking rumah yang disukai.

\section{SIMPULAN DAN SARAN}

\subsection{Simpulan}

Dari hasil pembuatan aplikasi ini kami dapat mengambil kesimpulan bahwa :

a) Aplikasi ini dapat menampilkan gambar rumah 3D dan denah rumah 3D pada saat menyorot marker.

b) Aplikasi ini dapat melihat gambar 3D sesuai posisi arah dari marker objek brosur yang disorot.

c) Kualitas marker dan pencahayaan yang cukup sangat mempengaruhi kecepatan pengenalan marker.

d) Membantu pelanggan untuk melalukan proses booking suatu rumah.

\subsection{Saran}

1. Aplikasi dapat dikembangkan kedalam bentuk video 3D.

2. Aplikasi ini dapat dikembangkan dengan memasukkan pengenalan audio.

\section{DAFTAR PUSTAKA}

Anditya. (2012). Panduan mudah membuat Visualisasi 3D Arsitektural, Seri Compact House, Griya kreasi, Medan.
Asbara, N. W. (2020). Pemanfaatan Augemented Reality (AR) Sebagai Media Pembelajaran Interaktif Pengenalan Huruf Hijaiyyah Berbasis Android. Jurnal Ilmu Komputer Dan Desain Komunikasi Visual, 5(1), 1-11.

Idris, M., \& Hidayat, M. (2020). Analisis Pengaruh Penerapan Sistem Informasi Manajemen Dan Standar Operasional Prosedur Terhadap Kinerja Pegawai Pada Dinas Pemberdayaan Masyarakat Desa Kabupaten Majene. AkMen JURNAL ILMIAH, 17(3), 438-449.

Latief, F. (2019). Dimensi relationship marketing terhadap loyalitas pelanggan indihome triple play pt telkom. Bongaya Journal for Research in Management (BJRM), 2(1), 11-16.

Chandra, Handi. (2012). 7 Jam Belajar Interaktif AutoCAD 2012 untuk 3 Dimensi, Maxikom, Palembang.

Perey, C. (2011). Print and Publishing and The Future of Augmented Reality.

Roger S. Pressman, (2010). Rekayasa Perangkat Lunak : Pendekatan Praktisi, Penerbit Andi Offset, Yogyakarta.

Safaat, Nazruddin H. (2011). Pemrograman Aplikasi Mobile Smartphone dan Tablet PC Berbasis Android, Penerbit Informatika, Bandung. 